\title{
Severe cavitating pulmonary tuberculosis complicated with extensive thrombosis
}

\author{
Luqman Safwan Fauzi 다, ' Sandesh Shrestha
}

${ }^{1}$ Internal Medicine, Pilgrim Hospital, Nottingham, UK ${ }^{2}$ Infectious Diseases, Nottingham University Hospitals NHS Trust, Nottingham, UK

\section{Correspondence to}

Dr Luqman Safwan Fauzi; luqman.fauzi@doctors.org.uk

Accepted 23 March 2021

\section{DESCRIPTION}

A 24-year-old woman from Eritrea was admitted to the emergency department with a 2-week history of progressive shortness of breath and productive cough. Her family also reported her rapidly declining weight over this time. She further complained of a chronic abdominal discomfort, without association with a change in bowel habit. She is normally fit and well with a previous history of medical abortion 3 months prior to admission. On examination, she appeared cachectic with a Body Mass Index of $13.2 \mathrm{~kg} / \mathrm{m}^{2}$. There was good air entry in her upper lung zones with marked reduction in her right base. She remained afebrile but had raised $\mathrm{C}$ reactive protein of $121 \mathrm{mg} / \mathrm{L}$. An urgent CT pulmonary angiogram (CTPA) highlighted an extensive right lung cavitation and a left lower lobe segmental pulmonary embolus (figure 1). A noncontrast-enhanced CT abdomen (figure 2) was also arranged and showed a filling defect throughout her inferior vena cava with involvement of her left internal iliac and femoral veins. Her sputum samples were positive for acid fast bacilli and she was commenced on quadruple antituberculosis (TB) therapy. Her tumour markers and antiphospholipid screen were unremarkable.

After a review by the haematology team, the patient's extensive venous thrombi are to be managed with subcutaneous low-molecular weight heparin. She subsequently developed ongoing rectal bleeding a few days later. No haemoptysis was noted. To minimise further risk of bleeding, a joint decision with the haematology team was made to split her $60 \mathrm{mg}$ daily enoxaparin treatment dose into $30 \mathrm{mg}$ subcutaneously two times per day. Her case has been further discussed across multiple

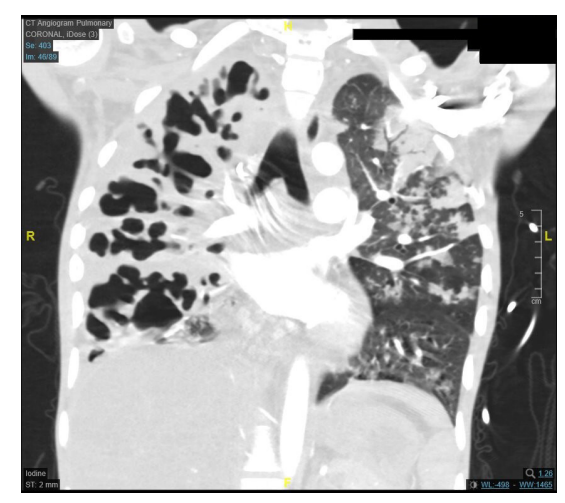

Figure 1 CT pulmonary angiogram showing destruction and cavitation of much of the patient's right lung parenchyma. There is also a left lower lobe posterior segmental pulmonary embolism.

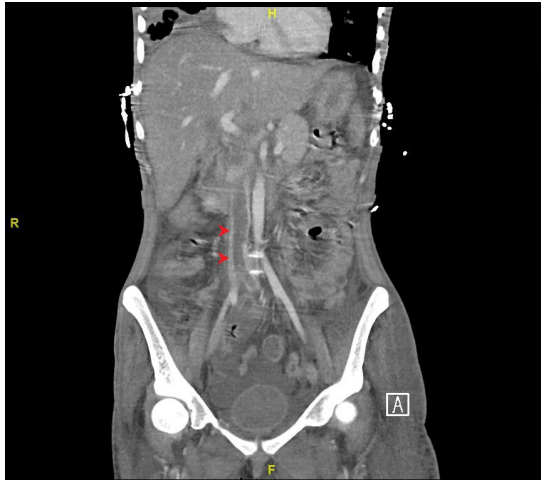

Figure 2 CT of the abdomen (contrast) showed a filling defect (red arrowheads) within the infrahepatic IVC extending throughout the length of the IVC and involving the left internal iliac and femoral vein. IVC, inferior vena cava.

specialties including the Intensive Treatment Unit (ITU) team, and she has been deemed for full escalatory care. In the case of significant haemodynamic instability secondary to a massive pulmonary embolism, she is to be treated with alteplase. This further emphasises the complicated nature of her $\mathrm{TB}$ and VTE-associated illness.

There is growing evidence that associates $\mathrm{TB}$ with thrombosis. One study has concluded a $2.07 \%$ prevalence of venous thromboembolism (VTE) in patients with active TB. ${ }^{1}$ Active TB has been shown to be linked with hypercoagulable state due to impaired fibrinolysis process. ${ }^{2} 3$ Turken et al observed patients with active pulmonary TB with raised plasma fibrinogen level, factor VIII, plasminogen activator inhibitor 1 and depressed antithrombin III level to have higher risk of developing deep vein thrombosis. ${ }^{3}$ These changes that alter

\section{Patient's perspective}

Perspective obtained from husband, main carer: she has been increasingly unwell for a few months and has been fully bedbound a few days prior to admission. I have asked her to seek immediate medical attention, but she is more fearful of catching COVID-19 in the hospital. Of note, her stomach ache has been there intermittently since a few weeks postabortion. I am happy that her condition has now stabilised after a few months being in the hospital, but a long stay in the hospital has impacted negatively on her motivation and mood. 


\section{Learning points}

- Patients with active tuberculosis (TB) are at higher risk of developing venous thromboembolism (VTE). We recommend having a low threshold to investigate VTE if suspected clinically.

- Acknowledge that pulmonary haemorrhage can be a serious complication of an overt anticoagulation in patients with cavitating pulmonary TB. A multidisciplinary approach is recommended in managing cases where deterioration is expected.

coagulation may be partly due to inflammation cascade released during chronic infection. Moreover, proinflammatory cytokines (tumour necrosis factor alpha, interleukin (IL)-1 and IL-6) are generated during an acute TB infection. ${ }^{4}$ They can induce production of acute inflammatory proteins and coagulation factors, further supporting a hypercoagulable environment. ${ }^{56}$

The patient underwent a repeat CTPA which later showed partial resolution of her previously seen pulmonary embolism. She remains as an inpatient with regular review by our dietician, physiotherapist and senior infectious diseases clinicians.
Contributors LSF and SS have been directly involved in the patient's care and have contributed towards the writing of this article.

Funding The authors have not declared a specific grant for this research from any funding agency in the public, commercial or not-for-profit sectors.

Competing interests None declared.

Patient consent for publication Obtained.

Provenance and peer review Not commissioned; externally peer reviewed.

\section{ORCID iD}

Luqman Safwan Fauzi http://orcid.org/0000-0001-6609-5637

\section{REFERENCES}

1 Dentan C, Epaulard O, Seynaeve D, et al. Active tuberculosis and venous thromboembolism: association according to international classification of diseases, ninth revision hospital discharge diagnosis codes. Clin Infect Dis 2014;58:495-501.

2 Robson SC, White NW, Aronson I, et al. Acute-Phase response and the hypercoagulable state in pulmonary tuberculosis. Br J Haematol 1996;93:943-9.

3 Turken 0 , Kunter E, Sezer M, et al. Hemostatic changes in active pulmonary tuberculosis. Int J Tuberc Lung Dis 2002;6:927-32.

4 Ogawa T, Uchida H, Kusumoto $Y$, et al. Increase in tumor necrosis factor alpha- and interleukin-6-secreting cells in peripheral blood mononuclear cells from subjects infected with Mycobacterium tuberculosis. Infect Immun 1991;59:3021-5.

5 Kerr R, Stirling D, Ludlam CA. Interleukin 6 and haemostasis. Br J Haematol 2001;115:3-12.

6 Gauldie J, Northemann W, Fey GH. II-6 functions as an exocrine hormone in inflammation. hepatocytes undergoing acute phase responses require exogenous IL-6. J Immunol 1990;144:3804-8.

Copyright 2021 BMJ Publishing Group. All rights reserved. For permission to reuse any of this content visit https://www.bmj.com/company/products-services/rights-and-licensing/permissions/

BMJ Case Report Fellows may re-use this article for personal use and teaching without any further permission.

Become a Fellow of BMJ Case Reports today and you can:

- Submit as many cases as you like

- Enjoy fast sympathetic peer review and rapid publication of accepted articles

- Access all the published articles

- Re-use any of the published material for personal use and teaching without further permission

\section{Customer Service}

If you have any further queries about your subscription, please contact our customer services team on +44 (0) 2071111105 or via email at support@bmj.com.

Visit casereports.bmj.com for more articles like this and to become a Fellow 